\title{
A quantitative study of mast cells in Hodgkin's disease
}

\author{
J CROCKER, PJ SMITH \\ From the Histopathology Department, East Birmingham Hospital, Bordesley Green East, \\ Birmingham B9 5ST
}

SUMMARY Mast cells were counted in 45 specimens from patients with Hodgkin's disease and in five lymph nodes showing follicular hyperplasia. A consistent finding was that of few mast cells in the lymphocyte depleted and lymphocyte predominant Rye subtypes of Hodgkin's disease and in the mixed cellularity variant; however, mast cells were much more prevalent in nodular sclerosing Hodgkin's disease and in the hyperplastic nodes. The mast cells were selectively stained by means of the astra blue technique.

There have been relatively few quantitative studies of Hodgkin's disease, no doubt as a result of the polymorphism of the component cells in this condition. A recent investigation of macrophage numbers in Hodgkin's disease ${ }^{1}$ gave rather surprising results in relation to Rye subtypes. In a further study, eosinophil polymorphs were counted in specimens from patients with Hodgkin's disease and in nodes showing follicular hyperplasia ${ }^{2}$ and significant differences were found between the numbers of these cells in the various subtypes of Hodgkin's disease. Mast cells, shown by positive staining with an immunohistochemical technique for factor VIII related antigen, have recently been observed subjectively to differ in numbers in Hodgkin's disease and follicular hyperplasia. ${ }^{3}$ Accordingly, we have counted mast cells in similar specimens.

\section{Material and methods}

\section{LYMPH NODES}

Forty five lymph nodes were examined from 45 patients. These comprised 20 specimens of nodular sclerosing Hodgkin's disease, 12 of lymphocyte predominant Hodgkin's disease, and 8 of the mixed cellularity subtype. In addition, five examples with lymphocyte depletion were included. A further five lymph nodes showing follicular hyperplasia were studied (Table 1).

FIXATION AND STAINING

The specimens were cut into $2 \mathrm{~mm}$ thick slices,

Accepted for publication 2 February 1984 which were then fixed in $10 \%$ formol-saline for $24-48 \mathrm{~h}$ at room temperature. The tissue was then dehydrated and embedded in paraffin wax and sections were cut at $2 \mu \mathrm{m}$ thickness. The sections were taken to $95 \%$ ethanol and stained in a solution of astra blue for 30-60 min. Excess stain was removed with $5 \%$ acid ethanol and the sections counterstained with Mayer's haemalum for $1 \mathrm{~min}$ (unblued), the recommended counterstain being an acidified acid fuchsin solution. ${ }^{4}$ The sections were then dehydrated, cleared, mounted, and examined for the presence of mast cells.

\section{COUNTING PROCEDURE}

Unlike previous quantitative studies of Hodgkin's disease, such as those in which eosinophil polymorphs $^{2}$ and macrophages ${ }^{1}$ were counted and expressed as a percentage of the total cell count, the numbers of mast cells were counted per 20 standard fields. This was necessary since even in specimens with many mast cells, these cells are relatively very sparse compared with eosinophils and macrophages. A $10 \times$ objective and $10 \times$ eyepieces, with a standard eyepiece grid graticule, were used; fields were selected at random.

In the case of nodular sclerosing Hodgkin's disease 10 fields each were taken from the fibrotic and the cellular areas; this was facilitated by virtue of the pale blue staining of collagen by astra blue.

\section{Results}

Mast cells were readily identified in the sections as cells staining intensely blue. Collagenous connective 
Table 1 Numbers of mast cells in specimens of Hodgkin's disease and follicular hyperplasia

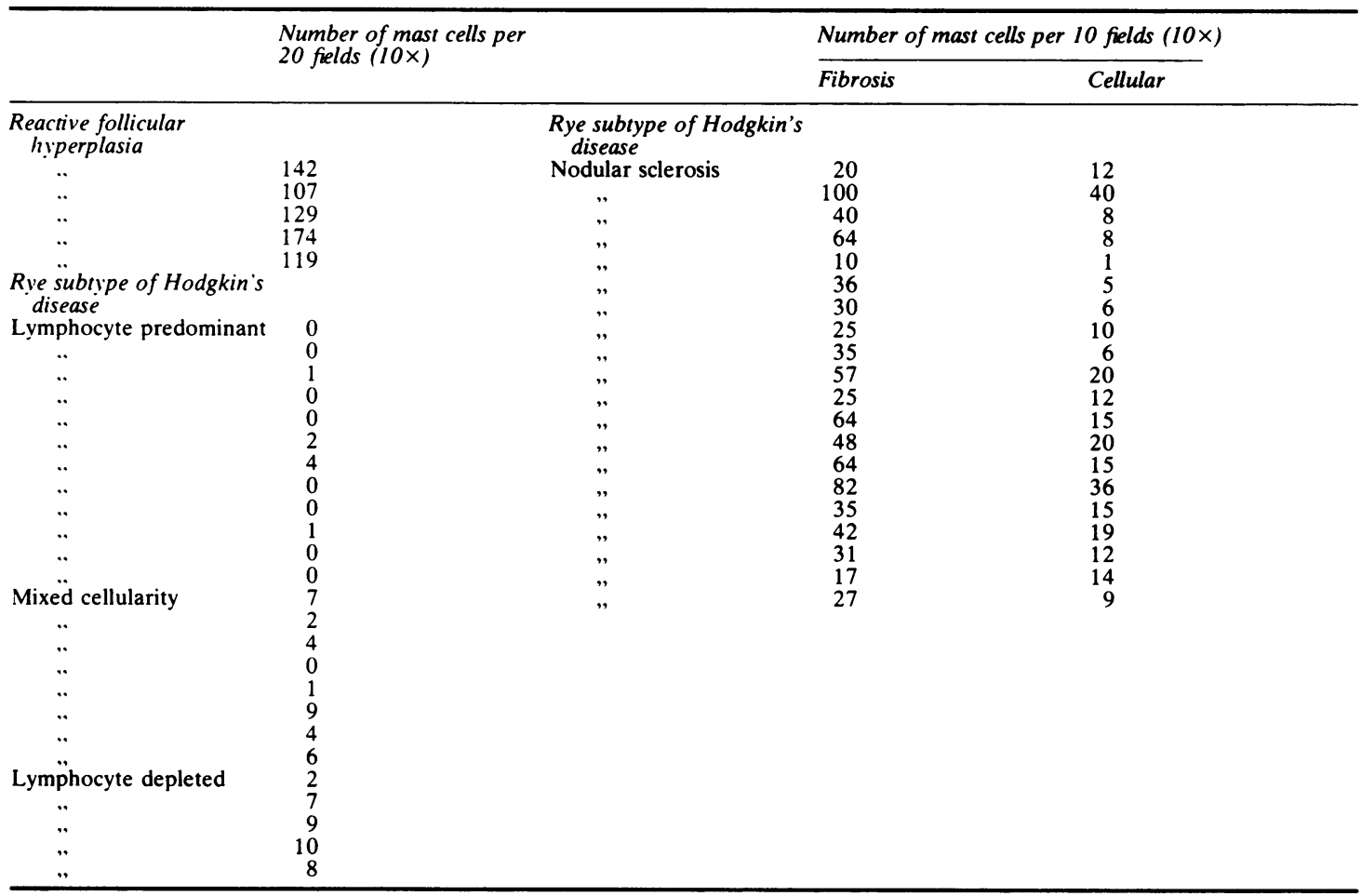

tissue stained a pale blue colour. Other cell types in lymphoid tissue were not stained.

Large numbers of mast cells were present in the specimens from patients with follicular hyperplasia, especially in and adjacent to the sinuses and in the interfollicular areas. These nodes contained from 107 to 174 mast cells $/ 20$ fields (mean $=134$ ).

Of the specimens from patients with Hodgkin's disease, those showing nodular sclersosis contained many more mast cells than the other subtypes. Thus in lymphocyte predominant Hodgkin's disease the numbers of mast cells per 20 fields ranged from 0 to 4 , in Hodgkin's disease of the mixed cellularity subtype from 0 to 9 , and in the lymphocyte depleted

Table 2 Mean numbers of mast cells for each pooled Rye subtype and for follicular hyperplasia

\begin{tabular}{|c|c|}
\hline & $\begin{array}{l}\text { Mean of pooled numbers of mast } \\
\text { cells } / 20 \text { fields }(10 \times)\end{array}$ \\
\hline $\begin{array}{l}\text { Rye subtype of Hodgkin's disea } \\
\text { Lymphocyte predominant } \\
\text { Nodular sclerosis } \\
\text { Mixed cellularity } \\
\text { Lymphocyte depletion }\end{array}$ & $\begin{array}{c}0.7 \\
57 \\
4 \\
7\end{array}$ \\
\hline Reactive follicular hyperplasia & 134 \\
\hline
\end{tabular}

variety from 2 to 10 (Table 1 ). The means of these pooled values are shown in Table 2 .

In all cases of nodular sclerosing Hodgkin's disease there were more mast cells in areas of fibrosis than in cellular zones; nonetheless, many mast cells were present in the latter and accounted for up to $82 \%$ of the total mast cell numbers. Indeed, the pooled mean numbers of mast cells per 10 fields, corrected by doubling, as if for 20 fields, was greater (28) than for the other Rye subtypes. The total numbers of mast cells per 20 fields (10 fields from fibrous and 10 from cellular areas) ranged from 11 to 140 and the numbers of these cells per 10 fibrous fields and per 10 cellular fields were from 10 to 100 and from 1 to 40 , respectively. The number of mast cells in nodular sclerosing Hodgkin's disease was significantly greater than in the other variants of the disease ( $\mathrm{p}<0.001$, Student's $t$ test).

\section{Discussion}

The functional role of mast cells in lymphoid tissues is uncertain. ${ }^{5}$ These cells are described as a normal constituent of lymph nodes, ${ }^{5}$ although it is uncertain whether they are "stationary" in these structures. They may leave the node by means of efferent lym- 
phatics, but Lennert ${ }^{6}$ has concluded that most mast cells remain in situ. It has also been shown that these cells may divide in the periphery as well as arising from bone marrow precursors. ${ }^{7}$ Mast cells, when shown by virtue of their content of factor VIII related antigen, ${ }^{3}$ tend to lie within or adjacent to medullary, intermediate, and subcapsular sinuses in "reactive" lymph nodes, and this disposition could be of some, as yet unknown, importance. In follicular hyperplasia mast cells are also prevalent in interfollicular areas or paracortex. ${ }^{38}$ Greatly increased numbers of mast cells have been found in the sinuses of nodes draining breast carcinomas, ${ }^{,}$and the question remains as to whether these cells arrive in the nodes from the bloodstream or divide locally.

The importance of the currently reported quantitative findings is unclear; nonetheless, it is apparent that many more mast cells are present in nodular sclerosing Hodgkin's disease than in the other Rye subtypes. This greater quantity does not merely reflect the fibrosis present in nodular sclerosing Hodgkin's disease, since proportionally more mast cells were present in the cellular areas than in the specimens from patients with lymphocyte predominant, mixed cellularity, and lymphocyte depleted Hodgkin's disease. It is of interest and possible importance that histamine, a major component of mast cell granules, may stimulate fibroblast proliferation ${ }^{10}$; thus the fibrotic process in nodular sclerosing Hodgkin's disease could be, in part, a result of mast cell degranulation. Of course, this does not explain the large numbers of mast cells in follicular hyperplasia, although degranulation may differ in these two conditions; this is most difficult to assess in sections. Histamine may also be partly responsible for the attraction of eosinophil polymorphs to inflammatory lesions ${ }^{1 \text {; }}$ however, we have shown previously that nodular sclerosing Hodgkin's disease does not contain an especially high number of eosinophils.'

Marrow mastocytosis has been found in patients with chronic lymphocytic leukaemia and nonHodgkin lymphomas affecting the bone marrow. ${ }^{12}$ In the context of malignant lymphomas, it is of interest that large numbers of mast cells have been described in bone marrow smears taken from patients with Waldenström's macroglobulinaemia. ${ }^{13}$ A similar content of these cells was not found in other diseases. Subsequently, the numbers of mast cells were counted in 58 cases of immunocytoma and were compared with the numbers in 34 cases of chronic lymphocytic leukaemia, ${ }^{14}$ using Giemsa stained sections. Many more mast cells were found in the lymphoplasmacytic type than in other immunocytomas or chronic lymphocytic leukaemia. The relevance of this finding is uncertain. To the best of our knowledge, quantitative studies of mast cells in Hodgkin's disease have not previously been performed.

It has been shown previously that nodular sclerosing Hodgkin's disease differs from the other Hodgkin subtypes in its possession of an apparently unique degree of vascularity. ${ }^{3}$ Evidence has now been presented that a further, unusual, hallmark of this Rye variety lies in the high content of mast cells. The paucity of quantitative studies of Hodgkin's disease has been stressed previously, ${ }^{12}$ is and the current findings, although empirical, emphasise the need for further such investigations. This is especially the case in view of the considerable interobserver disagreement in ascribing Rye subtypes to specimens of Hodgkin's disease. ${ }^{16}$ Discrepancies between the named varieties of Hodgkin's disease and genuine tissue differential cell counts have been shown, both by manual methods in "conventional" preparations of diffuse disease ${ }^{18}$ and by means of macrophage counts in all four subtypes, using enzyme histochemical methods.'

We are indebted to Mrs Ruth Fry for typing the manuscript.

\section{References}

' Crocker J, Jones EL, Curran RC. A quantitative study of $\alpha$-naphthyl acetate esterase-positive cells in Hodgkin's disease. J Clin Pathol 1982;35:1301-6.

${ }^{2}$ Fuggle WJ, Crocker J, Smith PJ. A quantitative study of eosinophil polymorphs in Hodgkin's disease. J Clin Pathol 1984;37:267-71.

${ }^{3}$ Crocker J, Smith PJ. Immunohistochemical localisation of factor VIII-related antigen in Hodgkin's disease. J Clin Pathol 1984;37:37-44.

${ }^{4}$ Blaies DM, William JF. A simplified method for staining mast cells with astra blue. Stain Tech 1981;56:91-4.

s Hunter RL, Ferguson DJ, Coppleson LW. Survival with mammary cancer related to the interaction of germinal centre hyperplasia and sinus histiocytosis in axillary and internal mammary lymph nodes. Cancer 1975;36:528-39.

- Lennert K. Malignant lymphomas other than Hodgkin's disease. New York: Springer-Verlag, 1978.

' Queisser W, Noeske K, Sandritter W, Lennert K. Cytophotometrische Untersuchungen des DNS-, Histon- und Gesampt proteingehalts von Epitheloidzellen, Gewebsmastzellen und von Zellen der Plasmocytopoiese bei käsige Lymphknotentuberkulose. Klin Wschr 1967;45:1135-42.

${ }^{8}$ Mahapatro RC, Bowers HM. Distribution of mast cells in the axillary lymph nodes of breast cancer patients. Cancer 1979;44:592-7.

- Thoreson S, Hartveit F. Mast cells and the nodal sinus reaction in breast cancer. Histopathology 1982;6:765-9.

${ }^{10}$ Russel JD, Russel SB, Trupin KM. The effect of histamine on the growth of cultured fibroblasts isolated from normal and keloid tissue. J Cell Physiol 1977;93:389-93.

"Clark RAF, Gallin JI, Kaplan AP. The selective eosinophil chemotactic activity of histamine. J Exp Med 1975;142: $1462-76$.

12 Yoo D, Lessin LS, Jensen W. Bone marrow mast cells in lymphoproliferative disorders. In: Pepys J, Edwards AM, eds. The 
mast cell, its role in health and disease. Tunbridge Wells, England: Pitman, 153-8.

${ }^{13}$ Tischendorf W, Hartmann F. Makroglobulinaemia (Waldenström) mit gleichzeitiger Hyperplasie der Gewebsmastzellen. Acta Haemat (Basel) 1950;4:374-83.

${ }^{14}$ Satodate R, Schwarze E-W, Lennert K. Gewebsmastzellenzahl bei Immunocytom und chronischer lymphatischer Leukäemie. Virchows Archiv A 1977;373:303-9.

is Crocker J. Morphometric and related quantitative techniques in the study of lymphoid neoplasms. A review.J Pathol 1984 (in press).

${ }^{16}$ Coppleson LW, Factor RM, Strum SB, Graff PW, Rappaport M. Observer disagreement in the classification and histology of Hodgkin's disease. J Natl Cancer Inst 1970;45:731-40.
${ }^{17}$ Holman CDJ, Matz LR, Finlay-Jones LR, et al. Inter-observer variation in the histopathological reporting of Hodgkin's disease: an analysis of diagnostic subcomponents using Kappa statistics. Histopathology 1983;7:399-407.

${ }^{18}$ Livesey EA, Sutherland FI, Brown RA, Beck JS, MacGillivray JB, Slidders W. Cytological basis of histological typing of diffuse Hodgkin's disease. Demonstration of an implied misnomer in the terminology of the Rye classification. J Clin Pathol 1978;31:551-9.

Requests for reprints to: Dr J Crocker, Department of Histopathology, East Birmingham Hospital, Bordesley Green East, Birmingham B9 5ST, England. 